\title{
Societal Reactions to the Corona Pandemic in the Netherlands
}

\author{
Freek Colombijn, Vrije Universiteit Amsterdam
}

\begin{abstract}
Every country in the world has to navigate the current Corona pandemic in its own way, taking national peculiarities into account. The government in the Netherlands has struggled to find a balance between the need for strict measures imposed in top-down manner, and the popular desire for individual freedom. The government has faced some open mass protest and more covert conspiracy theories circulating on Internet. Another problem for the Netherlands is the extremely open border, combined with the need to align national policies with policies of the European Union. The Corona pandemic has also had a positive effect, on new forms of solidarity and a slowing down of an overheated society.
\end{abstract}

Keywords: Corona Pandemic; Solidarity; Popular Protest; Accommodation; Everyday Resistance

\section{Introduction}

Every country in the world has to navigate the current Corona pandemic in its own way, taking national peculiarities into account. The aim of this paper is to discuss the peculiarities of the Corona pandemic in the Netherlands in order to offer material for a comparison with the situation in Indonesia. I do not try to point out the similarities and differences between Indonesia and the Netherlands myself; in a way this paper forms an assignment to the reader to develop this comparative framework. This search for comparisons stems from my background in anthropology, a discipline that has been defined as 'the comparative study of cultural and social life. Its most important method is participant observation, which consists in lengthy fieldwork in a specific social setting' (Eriksen 2015: 5). Social or cultural anthropology 'is about how different people can be, but it also tries to find out in what sense it can be said that all humans have something in common' (Eriksen 2015: 2).

The choice for the Netherlands is somewhat arbitrary and made purely on pragmatic grounds. Other member states of the European Union, or other countries in Asia or other continents would have yielded equally interesting, albeit different material for a comparison with Indonesia. According to figures provided by the state by mid-September there had been 2 million reported Covid-19 infections (out of a total population of 17.3 million residents); there have been over 18,000 deaths in total; and by mid-September $202182 \%$ of the adult population was vaccinated. Countries all over the world have found similar solutions (with the exception of a country like Brazil which has gone a different path) by a combination of vaccination and social distancing (including partial lockdowns, travel restrictions, and online teaching), but how these measures work out in practice varies greatly. In order to enlarge the 
potential for comparison I have formulated the research question in a broad manner as: how have Dutch people navigated the restrictions imposed on them during the Corona lockdown?

The situation in the Netherlands is different from Indonesia, because of its open borders in the European Union (simply closing borders is not a realistic option, at least not for any prolonged period of time) and the fact that it has to align its policies with those of other European Union states. Especially at the outbreak of the Corona pandemic in Europe and during the first months of the vaccination campaign "doing well" (that is: having low infection rates or high vaccination rates) became a matter of national prestige (or shame) and such a competition was mostly felt with other countries of the European Union.

Another difference with Indonesia is that the Netherlands have probably a relatively welldeveloped health care system, which hardly grants privileges to people with more money (or better political connections); in other words, if the health care system would collapse under the weight of sheer numbers of Covid-19 patients, the elite will suffer as much as ordinary people.

A last possible difference with Indonesia might be the stronger development of the democracy in the Netherlands. People would not accede to authoritarian behaviour of politicians and show less deference for people in power. Therefore the Dutch government cannot impose top-down measures, because people do not accept the implementation of policies based on no other legitimation than the power of the state. When the government issued the first restrictions (lockdown of schools and many companies) these measures were framed as an "intelligent lockdown" building on the goodwill of the people, in contrast to an enforced lockdown. The prime minister and the minister responsible for the Corona pandemic, Mark Rutte and Hugo de Jonge, announced the measures in weekly press-conferences broadcasted on television, which attracted large numbers of viewers.

Almost all restrictive measures have been recently lifted, but the few remaining restrictions evoke strong resistance. Throughout September and October 2021 there have been weekly demonstrations in the largest cities. They target in particular the requirement that one must show evidence of being fully vaccinated or a negative recent Covid-19 test, before one is admitted to restaurants, bars, museums, or concert halls. "We protest against the disproportionate measures against Covid-19 and the way our freedom is restricted and our citizens' rights ignored" and "Do you want to live as a QR code or as a human being" are some of the texts used on Facebook and banners to protest.

\section{Theoretical Framework}

This paper is loosely inspired by the work of Thomas Hylland Eriksen, already referred to in the Introduction, the concepts of habitus and everyday resistance.

Pierre Bourdieu gives various definitions of the concept of habitus, which does not help to directly understand what he meant. One way of putting it was: 'The habitus [...] ensures the active presence of past experiences, which, deposited in each organism in the form of schemes of perception, thought and action, tend to guarantee the "correctness" of practices and their constancy over time, more reliably than all formal rules and explicit norms. This system of dispositions -a present past that tends to perpetuate itself into the future by reactivation in similarly structured practices' (Bourdieu 1990: 54).

In his clearer style of writing Eriksen explains that Bourdieu uses the term habitus 'to describe enduring, learnt, embodied dispositions for action. The habitus is inscribed into the bodies and minds of humans as an internalised implicit programme for action. [...] Through habitus, the socially created world appears as natural and is taken for granted' (Eriksen 2015: 
115). People go through certain experiences and learn how to react in such circumstances. This knowledge is embodied in the sense that one's body reacts in certain situations (by gestures or movements) and that one does no longer think about one's behaviour and seemingly acts unconsciously. People with a similar class background go through similar experiences in their youth and tend to develop an identical habitus: 'Sociology treats as identical all biological individuals who, being the products of the same objective conditions, have the same habitus. A social class [... is] a class of biological individuals having the same habitus' (Bourdieu 1990: 59).

However, people do not merely surrender to their habitus and still have the freedom to explore alternatives. Antony Giddens argues that despite sometimes deeply engrained patterns of behaviour, people still have a choice: 'agency [... is] essentially the capability to have done otherwise' (Giddens \& Pierson 1998: 78)

During the Corona pandemic people were confronted with totally unfamiliar circumstances, so their habitus could no longer function as a routine 'plan of action'. Especially in the beginning of the Corona pandemic, commentators in media and experts sought for comparisons to interpret the new situation. The situation most often referred to was the Second World War. After the issuing of the first lockdown in March 2020, one embittered reaction to the initial reluctance to comply with the lockdown was: "your grandparents were asked to fight for their country, all that is required from you is to stay at home and sit on the couch; how difficult can that be?"

James Scott's concept of "weapons of the weak" explains why often people prefer smaller, everyday forms of resistance instead of open rebellion. Historically speaking large rebellions have usually been unsuccessful as they drew attention from those in power and could be quickly crushed. Small forms of resistance are more effective: backbiting; making fun of people in power; uncoordinated, but massive acts of defiance, and so on (Scott 1985). These forms of resistance were often encountered in reaction to state measures to minimize the free movement of people.

\section{Methodology}

The choice of the Netherlands was made because of the simple fact that I am resident of the Netherlands. Travel restrictions during the Corona pandemic would have made it difficult to do research in other places, except through online sources or with the help of local assistants. Data were collected by being in the Netherlands, living my life in Corona times, and following the news. No systematic data collection has taken place, but by talking to family, students, and friends, I have gathered additional information.

\section{Result and Discussion}

There have been various reactions to the Corona measures. The nature of these reactions have varied over time and were contingent on the degree of freedom to ignore restrictions, the state of the pandemic (and in particular the capacity of the health care system to cope with the number of patients, especially on Intensive Care wards), and the question whether measures were issued by the government or other organisations (companies, schools, universities, etcetera). Reactions also differed from one group to the other. For instance, vulnerable elderly people tended to be more in favour of Corona measures than youngsters with less health risks 
(and certainly a smaller chance to die from Covid-19) and more to lose from the closing of schools, universities, places of entertainment and sports clubs. In the remainder of this paper I will not try to assess how widespread particular patterns of behaviour were and merely point out that certain behaviour emerged.

The first reaction that stood out was a new form of egoism, when people stockpiled goods fearing a total lockdown of supermarkets. One good that was particularly hoarded was toiletpaper, which evoked a lot of sarcastic critique from commentators and humourists on television and other media. The Dutch term for hoarding (hamsteren, literally squirreling) has a rather neutral connotation, but the brilliant representation of the term by Irma Sluis, a sign language interpreter, during one of the press conferences of the prime ministers drove the message home that this behaviour is egoistic and undesirable.

However, at the same time new forms of altruism and solidarity appeared. People who had to go into quarantine were helped with their groceries by neighbours. Elderly who did not have to go into quarantine, but were worried to mix with the crowd in supermarkets were likewise helped. Such support could be given on ad hoc basis by neighbours, but was often times also quickly institutionalised by more permanent groups bringing around groceries on a large scale. Also schoolchildren could help by bringing homework to class mates who had to stay at home. Another form of solidarity was found in new forms of social contact. Children and grandchildren visited parents or grandparents but stayed outside of the homes of the elderly people. They talked through the window and sometimes one could see somebody who had brought a folding chair and a thermos with hot tea or coffee sit on the street and talk to somebody inside at the other side of the window.

Alongside new forms of egoism and altruism, older forms of protest appeared, but in new manifestations. Conspiracy theories circulate freely on Internet and are reinforced by the algorithms of search engines like Google. Possibly the most vocal group was called Viruswaanzin (Virus Madness), later renamed Viruswaarheid (Virus Truth). It denied the existence of a life-threatening Corona virus and on that ground rejected all state measures. Fundamentalist Christian communities that reject vaccinations ("because health and sickness are in the hands of God") also rejected vaccinations against the Corona virus on religious grounds. At the 2021 parliamentary election, one party, Forum voor Democratie, led by the demagogue Thierry Baudet, built its whole campaign on resistance against Corona measures of the government. Disregarding state measures to avoid crowds and to keep a distance, it organized large public rallies in which most people refused to wear a face mask. The populist politician Baudet shaked hands and hugged his political supporters in defiance of sound state recommendations to keep 1.5 metre distance. These forms of resistance are in themselves not particularly new, only the content of the protests against the established order had found a new target.

More innovative were the forms of everyday resistance. This kind of resistance was especially prominent among youngsters (adolescents and people in their twenties) who suffered under the closure of bars and other places of entertainment, or, at another phase during the pandemic, a curfew. Youngsters argued that such measures were counterproductive, because then people congregate at home, where the required social distancing was much more difficult to survey than in public bars or on terraces. They certainly have a point in this respect, but that is not the argument I wish to make. What matters here is how they adjusted their behaviour to the circumstances.

For instance, at a time when no more than two visitors were allowed at home (and bars were closed) a picture circulated on social media. It shows a youngster opening the door for a policeman who asks: "How many visitors do you have?" and the youngster answers: "two" 
(which was, as is implied in the joke, a lie). Policeman: "Would it be okay if I come in to check?". Answer: "No, because then I have three visitors in my home". This kind of mockery of authorities is an exemplary "weapon of the weak" (Scott 1985).

A very common form of resistance is the deliberate, wrong handling of face masks. About the first public space where face masks became mandatory, and about the only place where they are still mandatory as I write (October 2021) is in public transport. Only very few people enter trains and buses without a face masks (and they would usually be removed from the train or vehicle), but quite a few wear the mask only over their mouth and not their nose, or not even over their mouth (but on their chin). It is hard to tell whether they are fooling themselves or whether they know this is useless and meant as a modest sign of protest.

The youngsters have also found creative ways to circumvent the curfew (during those months a curfew was in place). The curfew lasted from 9 p.m. till 5 a.m. People in their twenties used to come together at their respective homes or in cafes and discos after 9 p.m. but this was no longer possible when the curfew was in place. One alternative was to start parties during daytime, so that everybody could go home before 9 p.m. The alternative was to make sure to be indoors by 9 p.m. and then party on until after 5 a.m. Needless to say that such behaviour rather increased the risk of spreading Covid-19 than decreased the risk. Neither solution to circumvent the curfew was considered wholly enjoyable by the youngsters, because they had to go home early or were forced to stay up till very late. Therefore at some moment it simply became more common to ignore the curfew, have gatherings at somebody's place and then race home (which is normally done by bicycle in the Netherlands and attracts less attention than travel by car or motorcycle) during the curfew.

One should not think that all youngsters were partying and were defying the curfew. Obviously that would be a wholly erroneous understanding of what went on. Most youngsters probably simply stayed within the confines of the anti-Corona regulations. One interesting change was the rediscovery of old traditional board games, which had the reputation of being unexciting and which were associated with either young children (in the age of primary school) or retired people in old people's homes. Suddenly youngsters discovered that these harmless games offered nice forms of making fun and conviviality.

\section{Conclusion}

While the worst of the Corona pandemic seems to be momentarily under control in the Netherlands (but with a new variant another cycle of rising infections set in), but the disease will stay with the country for a long time to come. It is an open question to what extent people return to their old habitus and to what extent new patterns of behaviour will stay. Will Dutch people continue to work more from home? Will there remain a bigger role for the state and shall less issues (like health care, but also education) be left in neo-liberal fashion by the market? Will people continue to keep more of a distance or will bodily contact for greetings (shaking hands, kissing on the cheek, hugging) return? Will the positive appreciation of science remain or will scientific ideas (in medical science, but also behavioural sciences) lose importance? Will new forms of solidarity stay? Only time will tell. 


\section{References}

[1] Bourdieu, Pierre (1990). The logic of practice, translated by Richard Nice [French original 1980]. Cambridge: Polity Press.

[2] Eriksen, Thomas Hylland (2015). Small places, large issues: An introduction to social and cultural anthropology [fourth edition]. London: Pluto Press.

[3] Giddens, Anthony and Christopher Pierson. 1998. Conversations with Anthony Giddens. Cambridge: Polity.

[4] Scott, James C. (1985). Weapons of the weak: everyday forms of peasant resistance. New Haven and London: Yale University Press. 